\title{
What are the characteristics of catering establishments more or less likely to provide healthier options for children across the island of Ireland?
}

\author{
R. K. Price ${ }^{1}$, L. McGuffin ${ }^{1}$, J. M. W. Wallace ${ }^{1}$, T. A. McCaffrey ${ }^{1,2}$ and M. B. E. Livingstone ${ }^{1}$ \\ ${ }^{1}$ Northern Ireland Centre for Food and Health (NICHE), University of Ulster, School of Biomedical Science, \\ Coleraine BT52 1SA, UK and ${ }^{2}$ Department of Nutrition and Dietetics, Monash University, VIC 3168, Australia
}

A major component of a child's eating environment is foods eaten out-of-home ${ }^{(1)}$. This is of concern as these foods are often associated with higher energy and fat intakes ${ }^{(2)}$, and lower micronutrient intakes ${ }^{(3)}$. Catering establishments have the potential to play a key role in influencing this eating behaviour by ensuring children have a healthier option available whilst eating out. The aim of this study was to investigate the characteristics of establishments who are more/less likely to provide healthier food options for children.

A telephone survey was conducted among a representative sample of caterers across the IOI ( $n$ 180; NI ( $n$ 60), RoI ( $n$ 120); cafés ( $n$ 22), fast food ( $n 40)$, restaurants $(n 81)$, pubs ( $n$ 37)). Information was collected on the characteristics of the eating establishment, its health-related cooking and menu practices, as well as perceptions of the managers/owners to their role and responsibilities in children's nutritional health. Of the 30 questions, responses to four questions were used to determine establishments more/less likely to provide healthier options for children, specifically 'Are there fruit options on the children's menu?' (yes, 48\%), 'Are there vegetable options on the children's menu?' (yes, 67\%), 'In light of recent interest and concern in children's diets, have you made any changes to your menu in the last year?' (yes, 32\%) or 'Are there any 'healthier' options on the menu for children?' (yes, 64\%). Using these questions crossanalyses (chi-squared analysis, Merlin software) were performed to investigate significant $(\mathrm{P}<0.05)$ differences in survey responses.

Of the 180 caterers surveyed $173(96 \%)$ reported having a separate children's menu $(76 \%)$ or that children could order smaller portions from the main menu.

Table 1. Characteristics of establishments more and less likely to provide healthier options for children ${ }^{\mathrm{a}}$

\begin{tabular}{|c|c|}
\hline Establishments more likely to provide healthier options for children & Establishments less likely to provide healthier options for children \\
\hline $\begin{array}{l}\text { Establishment characteristics } \\
\text { - Hotels } \\
\text { - Have no separate children's menu but a wide range of options for children }\end{array}$ & $\begin{array}{l}\text { - Fast food establishments } \\
\text { - Have a separate children's menu and a limited range of } \\
\text { options for children }\end{array}$ \\
\hline $\begin{array}{l}\text { Health-related practices } \\
\text { - Have made changes to their menu or cooking methods in the } \\
\text { last year to make them healthier } \\
\text { - Make food on the premises } \\
\text { - Use healthier cooking methods and season with pepper, herbs and spices } \\
\text { - Consider the children's menu important and actively promote it }\end{array}$ & $\begin{array}{l}\text { - Use less healthy cooking methods, e.g. deep fat frying } \\
\text { - Have made no changes to their menu or cooking methods } \\
\text { in the last year to make them healthier } \\
\text { - Do not consider the children's menu to be important }\end{array}$ \\
\hline $\begin{array}{l}\text { Manager/owners' perceptions } \\
\text { - Consider cost is not a limiting factor in providing healthier children's options } \\
\text { - Disagree that healthier food is less appealing }\end{array}$ & $\begin{array}{l}\text { - Consider that healthier options would not sell as well } \\
\text { - Have little intention of providing more healthier options in the future }\end{array}$ \\
\hline
\end{tabular}

These findings provide some useful insights into the characteristics of eating establishments more/less likely to provide healthy options for children. It is encouraging that establishments which do provide healthier options find they are both cost effective and that uptake is good. Findings also support current campaigns ${ }^{(4)}$ to provide main menu half-portions for children rather than having a separate children's menu. More research is needed however, on what impact the availability of healthier options has on children's food choices out of home.

This material is based upon works supported by safe food, the Food Safety Promotion Board, under Fund No. 02-2013.

1. Irish Universities Nutrition Alliance (2005) The National Children's Survey. Dublin.

2. Lachat et al. (2011) Obes Rev 13, 329-46.

3. Orfanos et al. (2009) Eur J Clin Nutr 63, S239-62.

4. Restaurant Association of Ireland, Me-sized Portions (www.rai.ie/news-kids-size-me-initiative--voluntary-guidelines-173.html). 